\title{
KONKRÉTAN AZ ABSZTRAKTRÓL
}

\author{
Veszelszki Ágnes \\ veszelszki.agnes@gmail.com
}

DO I : 10.20520/JEL - K EP.2018.4.71

\begin{abstract}
Absztrakt
A tudományos íráskészség-fejlesztés a fontosságához képest viszonylag elhanyagolt szövegtípusa az absztrakt. Ez a tudománykommunikáció egyik kitüntetett múfaja, hiszen ún. kapuőrző döntések kapcsolódnak hozzá. Az absztrakt mint tudományos szövegtípus jelentőségét két funkciója adja: egyrészt metatextuális funkcióban egy másik szöveg (szóbeli konferenciaelőadás vagy írott tanulmány) helyett áll, arra utal egyszerübb reprezentációként; másrészt a szövegre utaló tartalmi funkcióval is rendelkezik egy cikk - azzal azonos vagy attól eltérő nyelvü - kíséröjeként. Az absztrakt tehát rámutat a (tanulmány- vagy előadás)szövegre deiktikusan, illetve a szöveget képviseli (kvázi-)metonimikusan. Az összegzés, a parafrazeálás, gondolatok és információk szintetizálása az absztraktírás feltételéül szolgáló készségek. Jelen cikk az „academic writing” vonatkozó szakirodalmának elvárásait ütközteti száz, magyar nyelvü, különböző tudományterületről származó absztrakt empirikus szövegelemzésével.
\end{abstract}

\section{Kulcsszavak}

tudományos írás, tudománykommunikáció, absztrakt, szövegtan, tartalomelemzés

\section{ABSTRACTOF A BS TRACTS}

\section{Ágnes Veszelszki}

\begin{abstract}
Despite their importance, abstracts are relatively neglected in academic writing development. The abstract is a special genre of scientific communication as it has a gatekeeping role. The relevance of the abstract as an academic text type results from two of its functions: the metatextual function, whereby it replaces another text (oral or written paper) as a simpler representation, and the qualitative function, whereby it refers to the content of the text it accompanies (written in the same or another language). In other words, the abstract is both a deictic reference to the text (of the paper), and the (quasi-)metonymic representation thereof. The ability to summarise, paraphrase and synthesise ideas and information is essential in writing abstracts. This paper empirically assesses 100 Hungarian abstracts from various scientific fields against the requirements prescribed in the relevant literature on academic writing.
\end{abstract}

\section{Keywords}

academic writing, science communication, abstract, textology, text linguistics, content analysis 


\title{
KONKRÉTANAZ ABSZTRAKTRÓL
}

\author{
Veszelszki Ágnes
}

\section{Témamegjelölés és célok}

A tudományos íráskészség-fejlesztés (academic writing-oktatás) egy, a fontosságához képest elhanyagolt szövegtípusa az absztrakt. Ilie (2012: 242) meglátása szerint e szövegtípus az ún. kapuőrző döntések (gate-keeping decisions) alapját jelenti, hiszen egy konferenciajelentkezés elfogadásáról vagy egy tanulmány befogadásáról a bizottság rendszerint a beküldött absztrakt alapján dönt. Egy jól megírt absztrakt felhívja magára a folyóirat-szerkesztő figyelmét, megnöveli a tanulmány megjelenésének, a későbbiekben pedig az elolvasásának és mások általi idézésének az esélyét (Fallatah 2016: 368). A leendő tudósok szocializációjának részét kell képeznie a szakterületük számára releváns szövegtípusok ismeretének is (Gruber 2010: 17). Mindennek ellenére az absztraktírás mikéntjének elsajátítása nem vagy csupán mellékesen jelenik meg a tudományos pályára való felkészítés curriculumában. Ahogy Majchrazak és Salski (2016: 160) megjegyzi, az ilyen tudományos szövegformák elsajátítása leginkább a gyakorlatban, az írás folyamatában történik (a „learning by doing” módszerével), vagy esetleg korábbi, főként a konzulenstől származó minták átvétele, utánzása révén - ám explicit módon ez az ismeret ritkán jelenik meg. Pedig az absztraktírás feltételéül szolgáló készségek - az összegzés, a parafrazeálás, gondolatok és információk szintetizálása - a tudományos írás általános alapkészségei is (vö. Kitis et al. 2016: 121).

E tanulmány az absztraktokra vonatkozó szakirodalom elvárásait ütközteti száz, különböző tudományterületről származó, magyar nyelvű absztrakt szövegelemzésével.

\section{A tudományos írás (academic writing)}

\subsection{Jellemzöi}

Ugyan a tudományos közegnek is vannak szóbeli müfajai (mint a konferencia-előadás, székfoglaló stb.), a tudomány alapvetően írásos kultúra („Wissenschaft ist eine Schriftkultur”, Gruber 2010: 17). Az akadémiai szövegek tudományos állítások megfogalmazásának, ötletek kidolgozásának, kategóriák felállításának és lényeges különbségtételek kidolgozásának eszközeként alakultak ki, és egyúttal a kutatóknak a vizsgált témához és egymáshoz mint szakemberekhez füződő viszonyuk jelzésére is szolgálnak - állítja Ilie (2002: 3). ${ }^{1}$

${ }^{1}$ Eredetiben: „Academic textual practices have evolved as an instrument used for constructing knowledge claims, fostering ideas, identifying categories and concepts, as well as for developing relevant distinctions. [...] In their communicative and cognitive dimensions, these texts contribute to shaping the way in which academics relate to the investigated topic and to each other as professionals" (Ilie 2002: 3). 
A tudományos stílusréteg általános jellegzetessége az egyértelmü terminológia, az értelmi jellegü kifejezésmód túlsúlya (ezáltal az érzelmi hatású, expresszív nyelvi elemek kerülése), lehetőség szerint a választékos megfogalmazásmód. Mondatformálására a kijelentő modalitás a jellemző (a retorikai kérdés azonban gyakori eszköze), és általában világos szórendre, a logikus gondolatfüzésre törekszik (vö. Szathmári 2004). Gyakran alkalmaz vizuális stilisztikai eszközöket, felsorolásokat. Sajátossága az idézetek és hivatkozások használata (Veszelszki 2016).

\subsection{A tudományos írás müfajai}

Anélkül, hogy a müfaj (genre) és szövegtípus terminusok definiálásának széles körü és szerteágazó szakirodalmában elmerülnénk, térjünk ki röviden a szövegmüfaj funkcionális definíciójára. Swales (1990: 58) szerint a műfaj „kommunikációs események egy csoportját jelöli, amelynek tagjai hasonló kommunikációs célokkal bírnak. [...] Az egy müfajhoz tartozó szövegpéldányoknak nem csupán a céljuk közös, hanem a struktúrájukban, a stílusukban, a tartalmukban és a megcélzott közönségükben is hasonló mintázatot mutatnak". ${ }^{2}$ Más aspektust emel ki a Hyland-féle definíció, amely szerint a müfajok „a nyelv használatának absztrakt, társadalmilag elismert módjai"3 (Hyland 2002: 16). Gruber (2016: 24) meghatározásában a müfajok konkrét szövegelőfordulások absztrakciói, szándékos szociális-szemiotikai tevékenységek tipikus formái, amelyeket egy közösség használ és felismer. Leginkább a kommunikatív-szociális céljuk formálja őket, megvalósulásuk minden esetben kontextusfüggő - ezáltal ha a szövegkörnyezet változik, a müfajok is változnak.

A tudományos írás szövegformái nem diszkrét, egymástól élesen elkülönülő kategóriák, hanem egy kontinuumon helyezkednek el (Ilie 2002: 9). A tudományos stílusréteghez köthető főbb szövegműfajok többek között: szemináriumi dolgozat, szakdolgozat, diákköri dolgozat, folyóiratcikk, konferenciacikk, konferenciabeszámoló, tanulmánykötet, monográfia, tudományos ismeretterjesztő cikk (amely részben a publicisztikai stílushoz is tartozik), recenzió, vitairat, szótár, tankönyv, lexikonszócikk, illetve az itt részletesebben tárgyalt absztrakt, kivonat (vö. Szathmári 2004; Veszelszki 2015, 2016; Kitis et al. 2016: 121).

\subsection{A tudományos íráskészség elsajátítása}

A tudományos írás készségének a fejlesztésére az 1990-es évek elejétől kezdve fordítanak különös figyelmet. Nagy-Britanniában, az ún. academic literacies elmélet keretében kezdték el a témakört alaposabban tanulmányozni (ennek az oka az volt, hogy ebben az időben vált a korábbi szűkebb körü felsőoktatás tömegoktatássá, és az egységesség érdekében a különböző szociális és képzettségi háttérrel rendelkező diákoknak szükségük volt a tudományos írás módszertanának elsajátítására; Gruber-Huemer 2016: 83). Német környezetben a kérdéskör (wissenschaftliche Schreibkompetenz) sokáig a német mint idegen nyelv (DaF) és a didaktika körébe tartozott, a németet anyanyelvként beszélö, érettségizett diákoknál adottnak vették a tudományos írás kompetenciáját, és csak a kilencvenes évek végén vált az (anyanyelvi beszélő) egyetemi hallgatók íráskészségének tanulmányozása kanonizált nyelvészeti kutatási területté - állapítja meg Gruber és Huemer (2016: 83).

2 Eredetiben: „A genre comprises a class of communicative events, the members of which share some set of communicative purposes. [...] In addition to purpose, exemplars of a genre exhibit various patterns of similarity in terms of structure, style, content and intended audience" (Swales 1990: 58).

3 Eredetiben: ,abstract, socially recognized ways of using language” (Hyland 2002: 16). 
Gruber és szerzőtársai (2006: 26) Bourdieu (1992) nyomán elkülönítik egymástól a tudományos és az egyetemi szociális területet, ezáltal az átfedésekkel rendelkező tudományos és az egyetemi írást (,universitäres” und ,wissenschaftliches” Schreiben). A két doménben különböznek a pozíciók (hallgatók, oktatók vs. junior és szenior kutatók), a releváns tőkejavak (intézményspecifikus tudás és szövegtípus-kompetencia vs. diszciplínaspecifikus tudás és szövegtípus-kompetencia), az elsődleges tudásszerzés módja (biztos, tudományág-specifikus tudás vs. kutatói tudás) és a fö szövegmüfajok (jegyzet, kivonat, referátum, elöadás stb. vs. monográfia, tudományos folyóiratcikk, kézikönyv, recenzió, projekt-összefoglaló stb. - a szemináriumi és szakdolgozatok köztes pozíciót foglalnak el) (Gruber et al. 2006, Veszelszki 2016).

Gruber és Huemer (2016: 88) oktatói interjúkat és szemináriumi megfigyelési naplókat vizsgáló empirikus elemzése szerint az egyetemi oktatók a diákjaik írásos produktumaitól meglepően egységesen ugyanazokat várják el: tudományos stílus; egységes kinézet; jól követhető felépítés (,ein roter Faden”), világos érvelés és a megfelelően alátámasztott saját vélemény (ez utóbbival kapcsolatban nem volt teljes az egyetértés), a szakirodalom használata és helyes idézése. Meglepő eredmény, hogy a hallgatók e követelményeket nem a tudományos diskurzusra jellemző általános szövegnormaként, hanem az egyes oktatók egyéni elvárásaiként interpretálták - márpedig ha a diákok nem tartják kommunikatív, célorientált elveknek e kritériumokat, az megnehezíti a szövegtípus-kompetencia elsajátítását.

Reinmann és munkatársai (2011) a Writer’s Workshop módszer bevonását javasolják a doktori academic writing-oktatásba. Ez nagyjából a magyar doktori iskolák professzori szemináriumainak felel meg, és egy tudományos szöveg állandó, csoportos visszacsatolásokon keresztüli, folyamatközpontú fejlesztését célozza.

Gruber és szerzőtársai (2006) szerint az akadémiai szövegek (esettanulmányukban kifejezetten szemináriumi dolgozatokra vonatkozó) legfontosabb értékelési szempontjai a következők: makrostruktúra, koherencia, metakommunikáció (kontextualizálás, strukturálás, eligazodás a szövegstruktúrában, témaorientáció, megértést segítő metakommunikatív jelek), intertextualitás, érvelés, modalitás, lexika.

Kornmeier (2011: 34) szerint 70\%-ban a tartalom, 20\%-ban a stílus és 10\%-ban a forma számít a tudományos munkák értékelésekor. Bennett (2009: 44-45) a tudományos írásra felkészítő munkákban öt visszatérő alapelvet talált:

1. általános elvek (az academic writing explicit definíciói vagy az általános elvek kimondása): a világosság, a gazdaságosság, az objektivitás, a megfelelö érveléstechnika követelménye (ehhez még hozzátehetjük a téma relevanciáját);

2. szövegstruktúra: a tervezés szükségessége, a teljes szöveg strukturálása, a bekezdések szerkezete (tételmondat, mondatok száma egy bekezdésben), koherencia és kohézió;

3. grammatikai kérdések: mondatszerkezet és mondathosszúság, alárendelés és mellérendelés, aktív és passzív fogalmazás, időviszonyok, modalitás stb;

4. lexikai jellemzők: használandó és kerülendő szókincs, a szakszókincs használata;

5. egyéb: hivatkozás és idézés, plagizálás elkerülése, elméletek beépítése, empirikus adatok bemutatása.

E felsorolásban nem szerepel, de elhanyagolhatatlan szempont a müfajhoz (például lektorált folyóiratcikk, absztrakt, prezentáció, konferenciaposzter stb.) és az aktuális közönséghez való igazodás elve is. A követelmények listáját továbbá ki kell egészíteni a technikai és vizuális megformázással is (címek és alcímek hierarchiája, betüméretek és -típusok kiválasztása, bekezdésformázás, ábrák külleme, valamint az idézetek formai szempontból is pontos és következetes jelölése). 


\subsection{A tudományos szövegek kutatása}

A német nyelvtudományban önálló szubdiszciplína is létrejött a tudományos szövegek nyelvészeti vizsgálatára, Wissenschaftstextlinguistik (Gruber 2010) néven. Ide illeszkedik Ilie (2002) munkája, amelyben kétféle, a tudományos szövegekre jellemző metadiskurzust elemez: egyrészt az interperszonális, másrészt pedig a(z inter)textuális metadiskurzust. Az előbbi a közönség szerepére vonatkozik: a kutatóknak az állításaik elfogadása szempontjából kruciális, hogy ismerjék az olvasóközönségüket, az ő háttérismereteiket, érdeklődésüket, potenciális reakcióikat, és az írás során gyakorlatilag implicit-virtuális dialógust folytassanak olvasóikkal (Ilie 2002: 11). A kutató mediátorként, közvetítőként lép fel a saját szövege és a potenciális közönsége között (Ilie 2002: 4). A tudományos írás lényegében meggyőzésre törekszik, amelynek a hatékonysága azon múlik, az író mennyire képes leendő olvasói szükségleteit felismerni, kielégíteni és elvárásaiknak megfelelni (Ilie 2002: 11). Az interperszonális diskurzusnak különböző jelzései is vannak, amelyek a szövegíró elkötelezettségének és az olvasó bevonásának mértékét jelölik. Hyland (1999) négy ilyen jelzéstípust különít el: 1. az episztemikus modalitást jelölök (hedges, pl. talán, lehetséges) és a hangsúlyozásra szolgáló jelek (emphatics, pl. világosan, egyértelmüen) az író elkötelezettségét, bizonyosságát jelzik; 2. az attitüdjelölők (attitude markers, pl. meglepő módon) inkább a szövegalkotó érzelmi elkötelezettségére utalnak; 3. a kapcsolatjelölők (relational markers, pl. figyeljük meg a következö példát) explicit módon megszólítják az olvasót, ráirányítják a figyelmét valamire, vagy diskurzusrésztvevői szerepét hangsúlyozzák; végül 4. a személyjelölők (person markers) a szerző jelenlétét mutatják a szövegben, leggyakrabban az első személyü igealakokkal (angol eredetiben névmásokkal).

A másik metadiskurzus intertextuális jellegü: a tudományos szöveg (alkotója) és korábbi, hasonló témájú szövegek (és íróik) között jön létre. Gruber (2013) tudományos szövegeket értékelö munkájában kontinuumként ábrázolja: az egyik véglethez tartozó szöveg a kutatói közösség eredményeire alig hivatkozik, míg a másik véglet a kifejezetten sok szakirodalmi utalás (az nem világos, van-e „túl sok” hivatkozás). A tudományban tehát az intertextualitás explicit módon is megjelenik: éppen az idézések, hivatkozások révén (Jakobs 1999).

\section{Az ,absztraktok elmélete"}

Az absztrakt egy hosszabb tudományos szöveg (például cikk, szakdolgozat, disszertáció) rövid, precíz, világos - ám nem értékelő - összefoglalása, amely az alapvető gondolatokat, módszereket és a főbb eredményeket tartalmazza (vö. King-Bastalich 2016, Ilie 2012: 240, Azariadis 2017). Leggyakrabban elektronikus adatbázisokban, folyóiratcikkek és disszertációk részeként, illetve konferenciaprogram mellékleteként fordul elö; és két fö rendeltetése van: 1 . valamely döntés elösegítése (az olvasó elolvassa-e a hosszabb szöveget; a konferencia résztvevői az absztraktok és a cím alapján - is - döntenek, mely előadásokat hallgatják meg stb.); 2. információk indexelése, információmenedzsment a kulcsszavak segítségével (KingBastalich 2016). Ilie (2012) megkülönbözteti a jövőorientációjú absztraktokat (abstract) és a múltorientált összefoglalókat (summary), de elismeri, hogy e két típus között vannak átfedések. Az absztraktnak vannak általánosítható jellegzetességei és a gyakorlatban kialakult konvenciói, ám tudományterületenként eltérő információkat tartalmaz, és más-más elvárásoknak kell megfelelnie. ${ }^{4}$ Minden esetben fontos azonban, hogy eredeti és önálló szöveg

${ }^{4}$ Söt vannak interkulturális különbségek is. Például Fallatah (2016) összevetette a szaúd-arábiai és a nemzetközi célközönségre szabott absztraktokat, és a következőkben talált lényeges különbségeket: bőbeszédűség, ciklikusság, idézetek, felsorolások nagyobb mértékü használata, több bekezdés az arab közönségre szabott összefoglalókban. 
legyen, ne csupán egy kiemelt bekezdés vagy szövegrészlet: önmagában is, külső források használata vagy a hozzá tartozó cikk/dolgozat nélkül is érthető, koherens szövegként kell müködnie. Az absztraktírás további haszna, hogy amellett, hogy felhívja a szövegre a potenciális olvasók figyelmét, arra is szolgálhat, hogy a szerző önmagát ellenőrizze, tesztelje, hogy a tanulmánya, disszertációja valóban átlátható struktúrát követ-e, tartalmazza-e a lényeges makrostrukturális elemeket, és érthető-e az érvelése, követhető-e a gondolati íve - ezáltal a hosszabb szöveg diagnosztikai eszközeként is müködik az absztrakt (Azariadis 2017).

Meglátásom szerint az absztrakt mint tudományos szövegtípus jelentőségét két - a szöveg címéhez hasonló - funkciója adja: egyrészt metatextuális funkcióban egy másik szöveg (szóbeli konferencia-előadás vagy írott tanulmány) helyett áll, arra utal egyszerübb reprezentációként, másrészt pedig a szövegre utaló tartalmi funkcióval is rendelkezik egy cikk - azzal azonos vagy attól eltérő nyelvü - kísérőjeként (vö. a címről: Tolcsvai Nagy 2001: 325-326). Az absztrakt tehát rámutat a (tanulmány- vagy elöadás)szövegre deiktikusan, illetve a szöveget képviseli (kvázi-)metonimikusan. Az absztrakt mint a tudománykommunikáció egyik kitüntetett müfaja önálló kommunikációs egységként is létezik, ám egyben a szöveg részét is képezheti.

King és Bastalich (2016) háromféle absztrakttípust különít el egymástól: az informatív, a deskriptív és a vezetői összefoglalót. Az informatív (kérdés-válasz) típusú absztrakt a leggyakoribb, és elsősorban a kutatási folyamatról szól. Részei: az írás célja/oka (probléma, korábbi megoldatlan vagy új ügy), szakirodalmi áttekintés és annak esetleges hiányai, kutatási kérdés(ek) vagy hipotézisek, a kutatás módszertana, a legfontosabb eredmények, konklúzió és/vagy felhasználási lehetőségek. A deskriptív absztrakt egy kijelentésre, állításra, tézisre épül, amelyet bizonyítékokkal, adatokkal vagy egy vita kivonatolásával támaszt alá a szerző. Az informatív formától elsősorban abban különbözik, hogy nem tartalmaz kutatásmódszertani részt, hanem sokkal inkább egy diszkurzív érvrendszert épít fel. A két első típus elsődleges megcélzott közönsége az akadémiai közegből kerül ki. Vezetői összefoglaló (executive summary) is készülhet a tudományos szférában, például egy támogatás kutatási összegzéseként, egy pályázat elszámolásakor vagy egy kutatás üzleti vagy politikai hasznosítása céljából. Az előzőeknél lényegesen hosszabb, és mindig a legfontosabb eredményekkel kezdődik; a célra, a kiinduló kutatási problémára és a módszertanra viszonylag röviden tér ki - ehelyett a javaslatokra és indoklásukra helyez nagy hangsúlyt (kutatási absztraktokban ez a rész vagy elmarad, vagy kevésbé explicit); célközönségét pedig rendszerint a javaslatokat megvalósító szakemberek (gazdasági, politikai döntéshozók) alkotják.

Az absztraktírást megkönnyíti, ha a szerző kérdésekre válaszol. A legismertebb kérdéslista a Brown-féle nyolc kérdés (Brown 1994/95: 6, idézi Murray 2013: 131): 1. Kik a megcélzott olvasók? (Nevezzen meg hármat-ötöt név szerint is!) 2. Milyen kutatást végzett? 3. Miért? 4. Mi történt, milyen eredményekre jutott? 5. Mit jelentenek az eredmények elméletben? 6. Mit jelentenek az eredmények a gyakorlatban? 7. Mi a munka legfőbb tanulsága, hozadéka az olvasó számára? 8. Milyen problémák maradtak megoldatlanul, milyen kérdések megválaszolatlanul?

A kérdésekre való válaszadás mellett a másik módszer a négylépéses technika (Thomson-Kamler 2013). Az összefoglaló vagy absztrakt eszerint négy fö egységböl áll: 1. Elhelyezés (locate): helyezze el a cikket a diskurzusközösség kontextusában és általában a tudományterületen belül, nevezze meg a legfontosabb témákat és esetleges vitákat. 2. Fókusz (focus): emelje ki azokat a sajátos kérdéseket, ügyeket, problémákat, amelyeket a tanulmány megvizsgál. 3. Jelentés (report): mutassa be a kutatást, a mintát, az elemzés módszerét, hogy ezáltal az olvasó megbizonyodhasson a kapott adatok hitelességéről, megbízhatóságáról, végül mutassa be azokat a fő eredményeket, amelyek nélkülözhetetlenek az érveléshez. 4. Ér- 
velés (argue): mutassa be, magyarázza meg, helyezze (elméleti) kontextusba a fó eredményt, amelyre az elemzés révén jutott.

A harmadik absztraktírási módszer pedig a tartalom öt bekezdésre tagolása (Melbourne University 2010): 1. az írás célja/oka (a kutatás jelentősége; miért érdemes az olvasónak a hosszabb munkát is elolvasnia), 2. probléma (a megoldani kívánt ügy, a projekt kiterjedéseterjedelme, a legfontosabb állítása, feltételezése, tézise), 3. módszertan (kutatási módszerek, modellek, megközelítések, bizonyítékok), 4. eredmények (adatok, diszkusszió), 5. következtetések (hozzájárulás az adott szakterület tudásanyagához, az eredmények további elméleti jelentősége vagy gyakorlati hasznosíthatósága). Ezt az ötbekezdéses felosztást a tudományos íráskészség oktatása során homokóra-struktúrának szoktam nevezni: eszerint az ideális absztrakt a tágabb perspektívából indul, leszükíti azt a szerző saját kutatására, végül széles kontextusba helyezi az eredményeket.

King és Bastalich (2016) összegyüjtötte a ,jó” absztrakt jellemzőit:

1. nem lépi túl a megadott terjedelmet,

2. megfelelő a szerkezete és az információtagolása,

3. nem tartalmaz olyan (új) információt, amely nem szerepel a tanulmányban,

4. nincsenek benne definíciók,

5. nyelvi szempontból is megfelelö (vannak benne logikai átkötések, nincsenek benne stilisztikai vagy helyesírási hibák; az írás követhető az olvasó számára),

6. nem tartalmaz hivatkozásokat (ezzel kapcsolatban azonban megoszlanak a vélemények),

7. tartalmazza vagy felsorolja a kulcsszavakat.

Az absztraktíráshoz adott, preskriptív szemléletü tanácsok mellett az absztraktok elemzésének deskriptív módszere is létezik. Ennek fö keretrendszerét Swales (1981, 1990, Swales-Feak 2009) a tanulmányokat lépésekre (moves, steps) építő struktúrája adja. A lépés (move) funkcionális fogalma egy meghatározott és kötött, egy célra - a teljes szöveg céljára - irányuló kommunikatív cselekvésre utal (Lorés 2004: 282). Graetz (1985) a swalesi rendszer felhasználásával, empirikus elemzés alapján négy, az absztraktokban megjelenő retorikai lépést azonosított: Problem (probléma) - Method (módszer) - Results (eredmények) - Conclusion (konklúzió, következtetések). Ezzel szemben Salager-Meyer (1992, vö. Behnam - Golpour 2014) hat lépésröl beszél: Statement (állítás) - Purpose (cél) - Corpus/Method (korpusz/módszer) Results (eredmények) - Conclusion (konklúzió, következtetések) - Recommendation (javaslat). Ugyancsak Swales kategóriái nyomán Santos (1996) az összefoglalók struktúráját öt fö lépésben határozta meg (1. táblázat).

A lépések nem azonosíthatók minden esetben egyértelmüen az absztraktokban (Fallatah 2016). Sőt, azok elkülönítését nehezítheti, hogy az absztraktok tömörített, az információt sürítve közlő jellege miatt az egyes lépések hossza akár egy szótól vagy szószerkezettől több mondatig, bekezdésig is terjedhet (Povolná 2016: 33, Santos 1996: 458). Fallatah (2016) különbözö célközönségekre szabott vizsgálatában a következö szempontokat érvényesítette: 1. a fenti lépések jelenléte vagy hiánya, 2. sorrendjük, 3. átfedések, 4. idézetek használata, 5. felsorolások. Ilie (2012: 241) ugyancsak öt paraméter szerint elemezte az absztraktokat - elkülönítve azokat az összefoglalóktól (summary): 1. terjedelem és szelektivitás, 2. a szerző jelenléte (authorial presence) és az eredményeket értékelő attitüdje, 3. időbeli keret (a kutatás elött vagy utólag készül), 4. a fö szöveghez viszonyított hely (fö szöveg előtt, után vagy külön), 5. tartalom és hatókör (mennyiben tér ki a kontextusra, tágabb témakörre). Kaplan és szerzőtársai (1994) szintén öt paraméter szerint vizsgálódtak: 1. témaszerkezet, 2. grammatikai szerkezet, 3. pragmatikai lépések, 4. propozicionális elrendezés, 5. lexikai kohézió. 
1. táblázat

Az absztrakt öt lépése és azok funkciói (Santos 1996 alapján)

\begin{tabular}{|l|l|l|}
\hline Lépés (move) & Funkció & Kérdések \\
\hline $\begin{array}{l}\text { 1. kutatási szituáció } \\
\text { (situating the research, } \\
\text { STR) }\end{array}$ & A téma általános bemutatása & $\begin{array}{l}\text { Mit tudunk eddig a kutatás } \\
\text { témájáról, területéról? }\end{array}$ \\
\hline $\begin{array}{l}\text { 2. a kutatás bemutatása } \\
\text { (presenting the research, } \\
\text { PTR) }\end{array}$ & $\begin{array}{l}\text { Cél, kutatási kérdések, } \\
\text { hipotézis(ek) }\end{array}$ & Miről szól a kutatás? \\
\hline $\begin{array}{l}\text { 3. módszertan } \\
\text { (describing the } \\
\text { methodology, DTM) }\end{array}$ & $\begin{array}{l}\text { Anyag, korpusz, változók, } \\
\text { módszerek, eljárások stb. }\end{array}$ & $\begin{array}{l}\text { Hogyan végezték el a } \\
\text { kutatást? }\end{array}$ \\
\hline $\begin{array}{l}\text { 4. eredmények összegzése } \\
\text { (summarizing the } \\
\text { findings, STF) }\end{array}$ & A kutatás fö eredményei & Mire jutott a kutatás? \\
\hline $\begin{array}{l}\text { 5. értelmezések } \\
\text { (describing the research, } \\
\text { DTR) }\end{array}$ & $\begin{array}{l}\text { Az eredmények értelmezése, } \\
\text { alkalmazási lehetóségek, } \\
\text { javaslatok }\end{array}$ & $\begin{array}{l}\text { Mit jelentenek az } \\
\text { eredmények? Hogyan lehet } \\
\text { alkalmazni? }\end{array}$ \\
\hline
\end{tabular}

\section{Absztraktvizsgálat}

\subsection{Korpusz és módszertan}

Az előzőekben összefoglalt szakirodalmi eredmények figyelembevételével dolgoztam ki az empirikus kutatás szempontrendszerét, és a tartalomelemzés módszerét választottam a vizsgálathoz. Az absztraktvizsgálat sajátos nehézségét - az academic writing-oktatás előíró jellege miatt - az okozza, hogy a szövegelemzés meg tudjon maradni a deskriptív keretek között, és ne váltson át normatív szemléletre (ahogyan ezt Ilie 2012 is megfogalmazta).

Tartalomelemzésemhez 100, magyar nyelvü absztraktot gyüjtöttem össze korpuszként különböző tudományterületekröl (nyelvészet, jog, pedagógia, matematika, földtudományok, biológia, történelem, információtudomány stb.). Törekedtem arra is, hogy minél változatosabb tudományterületekről származzanak a magyar nyelvü absztraktok. Ebben nehézséget jelentett, hogy a magyar (címü) természettudományos szakfolyóiratokban sok esetben angol nyelvüek a cikkek és az előttük szereplő összefoglalók is. Ezúttal nem tettem különbséget a konferenciaabsztraktok (abstract) és a cikk-összefoglalók (summary) között. Csak nyilvános, már publikált absztraktok kerültek a gyüjteménybe. Az absztraktokat tehát online folyóiratokból és konferenciakötetekből gyüjtöttem 2018 tavaszán, a szerző(k) nevének feltüntetése nélkül. A szakirodalmi tradíciót követve én is öt szempontot választottam ki a vizsgálathoz: 1. az öt fö - Santos-féle - lépés jelenléte (aránya) vagy hiánya, 2. közönségorientáció (audience orientation), 3. a szerzői jelenlét, 4. írói elköteleződés és értékelő attitüd, 5. intertextualitás (idézések, hivatkozások, szakirodalmi lista). Eredetileg terveztem vizsgálni a terjedelmet is, ám mivel egyrészt ezt az adott folyóirat, tanulmány- vagy absztraktkötet szerkesztői meghatározhatták, másrészt szerkesztőként megváltoztathatták, nem lehet egyértelmüen a szerzői intenciókhoz kötni, így végül kihagytam az elemzésböl. A szöveghossz kapcsán csak egy érdekességre hívom fel a figyelmet: az absztraktszöveg terjedelmét rendszerint meg szokták 
szabni, ám a címét nem. Feltehetőleg ily módon kaphatta egy viszonyag rövidebb, nagy valószínüséggel terjedelmi kötöttségek közé szorított összefoglalószöveg ezt a címet:

(1) Az atipikus tanulás helyzete, kialakitásának lehetőségei, várható hatásai a pályaelhagyás megelözésének, a távozók outplacementjének biztositása érdekében a honvédségnél II. (Hazai és külföldi gyakorlat, a nemzeti közszolgálati egyetem egyes karait - föként a HHK-t -, karközi intézményeit és az mh altiszti akadémiát érintő strukturált riport és az online kérdöives vizsgálat egyes aspektusai ${ }^{5}$ )

A kódolást társkódoló bevonásával végeztem, az eredményeket táblázatban rögzítettem.

\subsection{Eredmények}

A lépések jelenléte vagy hiánya arra mutat rá, mennyire tipikus vagy atipikus az összefoglaló szöveg felépítése (1. ábra). A 100 absztraktból 89 a téma és annak szakirodalmi vagy egyéb hátterének bemutatásával kezdődött. A maradék 11 esetben a témát nem határozta meg a szerző, hanem azonnal a célkitüzésekre tért rá, vagy in medias res kezdődött a szöveg (2. példa). Meglepő módon arra, hogy miért végezte a kutató az adott vizsgálatot, milyen kutatási kérdésekkel vagy feltevésekkel, az absztraktoknak mindössze bö fele adott választ (57 esetben). Több esetben előfordult, hogy a szerzők sablon szerint dolgoztak, és az egyes részeket (célkitüzés, módszertan, eredmények, következtetések) explicit módon is jelölték (3. példa). Mindössze 71 esetben szerezhetett az olvasó arról tudomást, hogy a kutatók milyen módszerrel vagy anyagon dolgoztak. A kutatás eredményei 42 absztraktban kerültek elő (némely esetben az is csak sejtelmesen, lásd 4. példa) - ez azonban összefügghet azzal is, hogy konferenciaabsztraktok esetén a témát, a célokat és a módszereket már ismeri a szerző, de a kutatást még nem végezte el, arra csak a későbbiekben kerül sor. Meglepő eredmény azonban, hogy az eredmények közlése után a következtetésekre, a (várható) eredmények elméleti vagy gyakorlati hasznosíthatóságára, implikációira csupán 31 absztrakt tért ki (5. példa).

1. ábra

Az öt fö lépés jelenléte a 100 absztraktban (darabszám)

\begin{tabular}{|c|c|c|c|c|}
\hline A téma általános bemutatása & & & & \\
Cél, kutatási kérdések, hipotézis(ek) & & & & \\
Anyag, korpusz, változók, módszerek, \\
eljárások
\end{tabular}

5 A következőkben a példákat változtatás, javítás és forrásmegjelölés nélkül közlöm. A száz absztrakt összesített forrásjegyzéke a szakirodalmi lista előtt található. 
(2) A módszert Skóciában találták ki, hogy a motivációjukat vesztett gyermekek a tanulás élményeire, a szereplés örömére ismét rátaláljanak. (a szöveg első mondata)

(3) Bevezetés és Célkitüzés. Az idöskori kognitiv zavarok egészségügyi és szociális jelentösége növekszik az átlagéletkor fokozatos kitolódásával.

(4) Végezetül néhány statisztikai adatot szeretnék bemutatni az újszülöttek megölése számadatainak alakulásáról. (utolsó mondat)

(5) Következtetések: A negatív tendenciájú sporttáplálkozási tapasztalatok felhívják a figyelmet egy tudatosabb, edzésperiódusoknak megfelelö és szakember által összeállitott sporttáplálkozási program alkalmazására. A makro- és mikrotápanyagok bevitelével kapcsolatos eltérések kiküszöbölése nem csupán az egyéni és célzott étrend-kiegészités fontosságára hivják fel a figyelmet, hanem a teljesitményrontó életmódbeli tényezök szerepére is felhivják a szakértők figyelmét.

A közönségorientációt ebben az esetben a terminológia alapján vizsgáltam: aszerint, hogy a használt terminusok számára - feltehetőleg - a szélesebb közönség (6-7. példa), az adott tudományterület (8-9. példa) vagy csupán a szükebb kutatási téma ismeröi (10-11. példa) érthetik-e meg a szöveget. Anélkül, hogy erről pontos statisztika készült volna (a véletlenszerüen, nem rétegzett módon összeállított minta ezt nem tette lehetővé), megállapítható, hogy bár a bölcsészet- és társadalomtudományi szövegek kevesebb, a széles közönség számára nem érthető szakszót, rövidítést, mértékegységet tartalmaztak, mint a természettudományi kutatásokról számot adó absztraktok, ám ez nem volt minden esetben egyértelmü összefüggés. Az ezúttal a terminushasználattal mért közönségorientáció alapján koncentrikus körök halmazaként helyezhetök el az absztraktszövegek (2. ábra).

2. ábra

A közönségorientáció és a terminológia (darabszám)

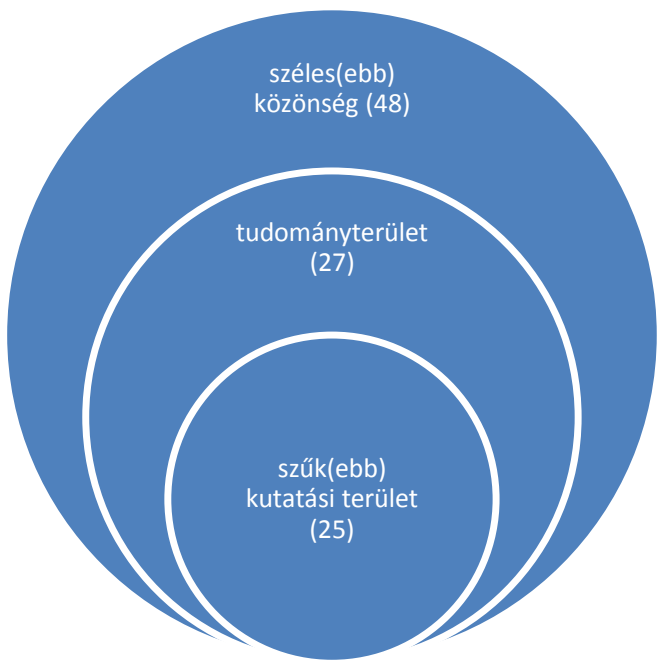

(6) A tragédiák, s a reneszánsz itáliai színház viszonya összetettebb annál, mintsem az 'újjászületés 'hagyományos toposzával leirható volna.

(7) A Duna - Ipoly Nemzeti Park Igazgatóság müködési területén a közönséges ürge (Spermophilus citellus) elsősorban homokos vagy löszös talajú, sik- és dombvidéki területeken fordul elö, ahol rendszeres legeltetés, vagy kaszálás biztositja a rövidfüvü gyepek fennmaradását. 
(8) A mikroalga számos szempontból kedvezö tulajdonsággal rendelkezik, leghatékonyabb energiaátalakitás az anaerob fermentációval érhetö el (Lakaniemi és mtsai, 2013).

(9) Az egyszeri szóalkotások kutatása a nyelvészet egy méltánytalanul elhanyagolt területe, ezért lenne célravezetö a késöbbiekben különféle korpuszok egyszeri szóalkotásait megvizsgálni, melyek egybevetésével az okkazionalizmusok sokfélesége is bemutathatóvá válna, és a fogalom differencializációjának szükségessége is bizonyitható lenne. Így fogalmi különbséget tehetnénk például az irodalmi müvekben elöforduló hapax legomenonok és a marketingben használt egyszeri szóalkotások között.

(10) Immunohisztokémiai vizsgálatok: Feláldozásuk után az agyból mértük a kolinerg neuronokból eredö axonok arborizációs mértékét a hippocampusban a kolin-acetiltranszferáz enzim (ChAT) immuncitokémiai festése útján Quantimet (Leica) és manuális módszerekkel.

(11) A zöngeminőségek manuális jelölése mellett mértem a spektrumban a harmonicitás zajhoz viszonyitott arányát a Praat programban (Boersma-Weenink 2013).

A szerzői jelenlét felmérésére négy kategóriát hoztam létre: az író nincs jelen, illetve E/3., $\mathrm{T} / 1$. és $\mathrm{E} / 1$. szám-személyben jelent meg a szerző. A 100 vizsgált absztraktból a leggyakrabban a többes szám első személyü jelölés fordult elö, mind többszerzős, mind egyszerzős munkák esetén (39 eset, 16. példa). 35 absztraktban nem volt megjelölve a szerző: vagy egyáltalán nem is volt rá utalás, vagy csupán „a kutatás, az előadás, a munka” stb. a mondatok alanya (12-14. példa), 24-szer a szövegíró egyes szám első személyben beszélt magáról (17. példa), és a legritkábban, háromszor az egyes szám harmadik személyü utalás jelent meg (15. példa). Kiemelendö, hogy az egyes szám első személyü fogalmazás öt esetben is az absztrakt müfajához nem illő, csupán terjedelemnövelő, ám egészen hosszú, akár vallomásszerü önéletrajzi kitérőkhöz is kapcsolódott (18. példa).

(12) A kognitiv nyelvészet a metaforát mint konceptuális folyamatot és terméket értelmezi, amely egy fogalmat egy másik fogalmon keresztül értelmez (Lakoff és Johnson 1980). A konceptuális metafora elsösorban a gondolatban létezik, emiatt pedig nem csak a nyelvben juthat kifejezésre, hanem más módokban is, például képekben, gesztusokban, nonverbális hangokban vagy zenében, ami a monomodális és multimodális metaforák széles spektrumát eredményezi (Forceville 2008, 2009). (nincs jelen a szerzö)

(13) A kutatás ezt a komplex viszonyrendszert igyekszik feltárni. (nincs jelen a szerző)

(14) A hozzászólás az irónia problémáját elméleti kiindulópontból teszi reflexió tárgyává. A funkcionális kognitív pragmatika perspektíváját értelmezve az irónia metapragmatikai természetére kívánja ráirányitani a figyelmet. (nincs jelen a szerzö)

(15) Ezt követöen a szerzö bemutatja a müfaj alkotóinak elképzeléseit az informatikai forradalom lehetséges eredményeiröl, következményeiröl. (E/3.)

(16) Jelen vizsgálatunkban szerettük volna jobban megérteni azokat a mögöttes kognitív struktúrákat, melyek hozzájárulnak a kapcsolatok milyensége által meghatározott társas hálózati komplexitáshoz. (T/1., egy szerző!) 
Hazai kutatások hiányában a jogfejlödést elösegitheti a különbözö külföldi jogrendszerek által alkalmazott megoldások, illetve az ott folytatott kutatások elemzése is, ezért a jelen elöadásomhoz a németországi kutatásokat, illetve az ott alkalmazott alternatív vitarendezési megoldásokat vizsgáltam meg. (E/1.)

(18) Környezetfizika iránti érdeklödésem már BSc-s szakdolgozatomban megjelenik, elsösorban környezetben megtalálható radioaktiv izotópok vizsgálatával foglalkozom, kitekintésként kezdtem el foglalkozni a toxikus fémtartalom vizsgálati lehetöségeivel. Dr. [név] egy korábbi szakdolgozója által vett, jól dokumentált Budapest XI. kerületéböl származó minták vizsgálatára kaptam lehetöséget. (E/1.)

Az előző eredmények alapján arra számítottam, hogy az írói elköteleződés jelei (episztemikus modalitás, értékelés, attitüd kifejezése) sokkal erőteljesebben lesznek jelen a szövegekben, ehhez képest elenyésző volt az arányuk (a bizonyosságra-bizonytalanságra 7-szer utaltak a szerzők [20. példa], valamilyen jellegü értékelö megnyilvánulás 9 szövegben fordult elő, mindegyikben csupán egyszer [21-22. példa]).

(20) Ez számos más tényezö mellett (célcsoport, digitális irástudás, információs müveltség, a projekt jellege és tartalma) feltehetöen attól függ, hogy a projekt mennyire támaszkodik az önszervezödö online csoport(ok)ra, illetve az elektronikus platformok kialakitása és gondozása (beleértve a diskurzusok facilitálását is) mennyiben segíti elö az önszervezödési folyamatokat.

(21) Az elmúlt húsz évben a nagy nemzetközi borversenyeken szép sikereket érnek el a magyar borok, sok érmet kapnak.

(22) Ahogy ez lenni szokott, önjelölt szakértök a tragédiasorozattal egy idöben interpretálták az eseményeket, sok esetben választott politikai oldaluk által hangoztatott gondolatmankóknak megfelelöen.

Az absztraktok nagy többsége semmilyen intertextuális utalást nem tartalmaz. 26 szövegben vannak (irodalomjegyzékkel is feloldott vagy feloldás nélküli, rövidített) hivatkozások (24. példa), 13 szöveg tartalmaz hivatkozás nélküli utalást (25-26. példa), 9-hez füzött a szerző irodalomjegyzéket, és háromban szerepel jelölt idézet (23. példa).

(23) Trudgill ezt így írja le: „egy közösség beszélöinek beszédszokásai fokozatosan megváltoznak, ahogy a beszélök öregszenek” (Trudgill 1997). (idézet)

(24) Bár egyre több hazai kutatás irányul az enyhén értelmi fogyatékos fiatalok személyiségalakulásának és szociális jártasságának pontosabb megismerésére (pl. Kasik et al., 2011; Szekeres, 2008), még számos olyan tényezö van, melynek fejlödését, szervezödését nem ismerjük e populációt illetően. Az észlelt énhatékonyság vizsgálatát indokolja, hogy a személyiségfejlödésben és a viselkedésben központi jelentöséggel bír (Rózsa és Kö). Hatással van a kognícióra, a motivációra, az érzelmekre és a viselkedésre (Bandura, 1993), az egészséges, adaptív emberi funkcionálás fontos tényezője (Kincheloe és Horn, 2007). (hivatkozások)

(25) A téma megértéséhez egy saját adatbázis, és annak elemzése, valamint egy pár évvel ezelött, az Országgyülés akkori képviselönőivel készitett kérdöíves kutatás visz közelebb, melynek alapjául egy Dr. Joy V. Peluchette, Dr. Katherine Karl és Dr. Kathleen Rust által készitett kutatás módszertana szolgált. (hivatkozás nélküli utalás, névvel)

(26) Ezek hatékonysága - az erre irányuló kutatások alapján - nem csak a tanulási eredmények növekedésében mérhető... (hivatkozás nélküli utalás, általánosan) 


\section{5. Összefoglalás}

A tudományos írás alapelveiből kiindulva az absztrakthoz kapcsolódó gyakorlati útmutatókon és az absztraktok alkalmazott nyelvészeti, elméleti kutatásán át száz magyar, különböző tudományterületekről származó absztrakt empirikus kutatásáig, tartalomelemzéséig tartott e cikk gondolati íve. Az öt alapvető struktuális egység vizsgálata alapján megállapítható, hogy az absztraktírók nem minden esetben vezetik be az olvasót a témába (és egyes absztraktok mindössze eddig jutnak: a szakirodalmat foglalják össze); az esetek több mint felében nem árulják el, mi a kutatás, előadás, tanulmány stb. célja (kérdése, hipotézise); arra ugyan általában, az esetek bő kétharmadában kitérnek, mi alapján jutottak az eredményeikre, ezeket viszont csak az esetek bő egyharmadában árulják el az absztraktban. És arra, hogy az eredményekből mire lehet következtetni, mi volt a haszna a kutatásnak - csupán az összefoglalók kevesebb, mint egyharmada tartja fontosnak kitérni. Márpedig a kitüzött célok, az elért eredmények és a levonható tanulságok deklarálása és explicitté tétele segítene a tudományos kutatás relevanciájának jelzésében, különös tekintettel arra, hogy az absztraktok a tudományban ún. kapuőri döntések eszközeként szolgálnak.

Ez a kutatás megerősítette azt a szakirodalmi vélekedést, hogy az absztrakt objektivitásra törekvő, nem a szerzőt hangsúlyozó müfaj (a vizsgált szövegek bő egyharmadában egyáltalán nem jelent meg a szerzőre utalás, másik bő egyharmadában a szerzőséget a személytől eltávolító $\mathrm{T} / 1$. forma jelent meg, és a szövegek negyedében volt jelen az író egyes szám első személyben). Ugyancsak erre a távolságtartásra utal a modalitásjelölők viszonylag alacsony megjelenési aránya. A közönségorientáció és a terminushasználat kapcsolatát vizsgáló részelemzést a későbbiekben érdemes lenne a tudományterületi összefüggésben is megnézni, egyelöre a célközönségeket sikerült egy kontinuumon elhelyezni, és megállapítani, hogy a szövegek közel fele a szakszóhasználat alapján a szélesebb, érdeklődő közönség számára is érthető. A szakirodalom és az útmutatók szerint az absztraktba nem célszerü vendégszövegeket elhelyezni, hiszen az arra szolgál, hogy az adott kutató saját munkáját mutassa meg - a vizsgált szövegek legnagyobb része megfelel ennek az elvárásnak. Megjegyzendő azonban, hogy ugyancsak elvárás, hogy az absztrakt önálló szövegként is létezzen, ezzel szemben viszont az absztraktok közel négytizede tartalmazott hivatkozást vagy hivatkozás nélküli utalást, amelyek a szöveghez füzött szakirodalmi lista nélkül gyakorlatilag értelmezhetetlenek, hibás linkek. Az összegyüjtött korpuszon (vagy esetleg annak bővített, tudományterületenként osztályozott változatán) további vizsgálatokat lehet végezni: az egyes lépések sorrendje, stilisztikai szempontok, fogalmazástechnika, tesztalanyokkal az érthetőség, koherencia stb. szempontok alapján.

Az absztraktok terjedelmével ezúttal nem foglalkoztam, ám e tanulmány zárásaképpen egy, a terjedelme miatt feltünő és kitünő absztraktra utalok. A tudományos írással foglalkozó tweetekben visszatérő példa (Shea 2011) a világ talán legrövidebb absztraktja, amely az arXiv tudományos oldalon, Can Apparent Superluminal Neutrino Speeds Be Explained as a Quantum Weak Measurement? eldöntendö kérdést tartalmazó címen megjelent cikkhez tartozik. Íme, teljes terjedelmében: Probably not. 'talán nem'. 


\section{IRODALOM}

Azariadis, Michael (2017) Writing your abstract. GRS Writing Seminar, 10th August 2017. The University of Western Australia.

Behnam, Biook - Golpour, Farhad (2014) A Genre Analysis of English and Iranian Research Articles Abstracts in Applied Linguistics and Mathematics. International Journal of Applied Linguistics \& English Literature, $3 / 5$ (September 2014). https://doi.org/10.7575/aiac.ijalel.v.3n.5p.173

Bennett, Karen (2009) English Academic Style Manuals: A Survey. Journal of English for Academic Purposes, 8. 43-54. https://doi.org/10.1016/j.jeap.2008.12.003

Bourdieu, Pierre (1992) Homo academicus. Frankfurt am Main, Suhrkamp.

Brown, Robert (1994/1995) Write Right First Time. Literati Newsline. http://web.archive.org/web/19971014014626/http://www.mcb.co.uk/literati/write.htm

Fallatah, Wafaa (2016) Features of Saudi English Research Articles Abstracts. Arab World English Journal (AWEJ), 7/2. 368-379. https://doi.org/10.24093/awej/vol7no2.25

Graetz, Naomi (1985) Teaching EFL students to extract structural information from abstracts. In: Ulign, Jan M. - Pugh, Anthony K. (szerk.) Reading for professional purposes: Methods and materials in teaching languages. Leuven, Acco. 123-135.

Gruber, Helmut - Huemer, Birgit (2016) Studentisches Schreiben erforschen und lehren: Grundlagenforschung und ihre Umsetzung in ein Kursprogramm. ZFHE, 11/2 (Mai 2016). 81-101. https://doi.org/10.3217/zfhe-11-02/05

Gruber, Helmut - Rheindorf, Markus - Wetschanow, Karin - Reisigl, Martin - Muntigl, Peter - Czinglar, Christine (2006) Genre, Habitus und wissenschaftliches Schreiben. Münster, LIT.

Gruber, Helmut (2010) Modelle des wissenschaftlichen Schreibens. Ein Überblick über zentrale Ansätze und Theorien. In: Saxalber, Annemarie - Esterl, Ursula (szerk.) Schreibprozesse begleiten. Vom schulischen zum universitären Schreiben. Innsbruck-WienBozen, Studien Verlag. 17-39.

Gruber, Helmut (2013) Das universitäre Schreiben Studierender. Grundlagenforschung und ihre Umsetzung in einem Kursprogramm. In: Katelhön, Peggy - Costa, Marcella Libero, Maria-Antonia de - Cinato, Lucia (szerk.) Mit Deutsch in den Beruf. Berufsbezogener Deutschunterricht an Unversitäten. Wien, Praesens Verlag. 174-192.

Gruber, Helmut (2016) Austria. In: Kruse, Otto - Chitez, Madalina - Rodriguez, Brittany Castello, Montserrat (szerk.) Exploring European Writing Cultures. Country Reports on Genres, Writing Practices and Languages Used in European Higher Education. Zürich, ZHAW School of Applied Linguistics. 24-35.

Hyland, Ken (2002) Teaching and Researching Writing. London, Pearson Education.

Hyland, Ken (1999) Talking to students: Metadiscourse in introductory coursebooks. English for Specific Purposes 18/1. 3-26. https://doi.org/10.1016/S0889-4906(97)00025-2

Ilie, Cornelia (2002) Who's afraid of Paul Grice? The role of the cooperative principle in academic metadiscourse. Rask, 16. 3-32. 
Ilie, Cornelia (2012) Comparing Genres of Academic writing: Abstracts and Summaries. In: Torrance, Mark - Alamargot, Denis - Castello, Montserrat - Ganier, Franck - Kruse, Otto - Mangen, Anne - Tolchinsky, Liliana - van Waes, Luuk (szerk.) Learning to write effectively: Current trends in European research. UK et al., Emerald.

Jakobs, Eva-Maria (1999) Textvernetzung in den Wissenschaften. Zitat und Verweis als Ergebnis rezeptiven, reproduktiven und produktiven Handelns. Tübingen, Max Niemeyer Verlag. https://doi.org/10.1515/9783110945928

Kaplan, Robert B. - Cantor, Selena - Hagstrom, Cynthia - Kamhi-Stein, Lia D. - Shiotani, Yumiko - Boyd Zimmerman, Cheryl (1994) On abstract writing. Text \& Talk. An Interdisciplinary Journal of Language, Discourse \& Communication Studies, 14/3. 401-426. https://doi.org/10.1515/text.1.1994.14.3.401

King, Debra - Bastalich, Wendy (2016) Abstract writing: Purposes, conventions and types. https://lo.unisa.edu.au/mod/page/view.php?id=489391

Kitis, Eliza - Hatzitheodorou, Anna-Maria - Kontouli, Cleopatra - Mattheoudakis, Marina (2016) Greece. In: Kruse, Otto - Chitez, Madalina - Rodriguez, Brittany - Castello, Montserrat (szerk.) Exploring European Writing Cultures. Country Reports on Genres, Writing Practices and Languages Used in European Higher Education. Zürich, ZHAW School of Applied Linguistics. 103-133.

Kornmeier, Martin (2011) Wissenschaftlich schreiben leicht gemacht für Bachelor, Master und Dissertation. 4., aktualisierte Auflage. Bern-Stuttgart-Wien, Haupt Verlag.

Kruse, Otto - Chitez, Madalina - Rodriguez, Brittany - Castello, Montserrat (2016) Exploring European Writing Cultures. Country Reports on Genres, Writing Practices and Languages Used in European Higher Education. Working Papers in Applied Linguistics 10. Winterthur, ZHAW Zürcher Hochschule für Angewandte Wissenschaften.

Lorés, Rosa (2004) On RA abstracts: from rhetorical structure to thematic organisation. English for Specific Purposes, 23/3. 280-302. https://doi.org/10.1016/j.esp.2003.06.001

Majchrazak, Ola - Salski, Łukasz (2016) Poland. In Kruse, Otto - Chitez, Madalina - Rodriguez, Brittany - Castello, Montserrat (szerk.): Exploring European Writing Cultures. Country Reports on Genres, Writing Practices and Languages Used in European Higher Education. Zürich, ZHAW School of Applied Linguistics. 151-164.

Melbourne University (2010) Writing an abstract. Understanding and developing abstracts. Academic Skills. http://www.services.unimelb.edu.au/academicskills

Murray, Rowena (2013) Writing for academic journals. Maidenhead, Open University Press.

Povolná, Renata (2016) Cross-cultural analysis of conference abstracts. Discourse and Interaction, 9/1. 29-48. https://doi.org/10.5817/DI2016-1-29

Reinmann, Gabi - Sippel, Silvia - Florian, Alexander - Ranner, Tamara - Kamper, Marianne (2011) Förderung wissenschaftlichen Schreibens in der Doktorandenausbildung mit Writer's Workshops: Eine Fallstudie. Personal- und Organisationsentwicklung 6/2-3. $32-39$.

Salager-Meyer, Françoise (1992) A text-type and move analysis study of verb tense and modality distribution in medical English abstracts. English for Specific Purposes, 11/2. 93-113. https://doi.org/10.1016/S0889-4906(05)80002-X

Santos, Mauro B. dos (1996) The textual organization of research paper abstracts in applied linguistics. Text, 16. 481-499. https://doi.org/10.1515/text.1.1996.16.4.481 
Shea, Christopher (2011) Best Abstract on a Scientific Paper Ever? http://blogs.wsj.com/ideas-market/2011/10/27/best-abstract-on-a-scientific-paper-ever/? $\underline{\bmod =W S J B l o g}$ (October 27, 2011, 9:49 AM ET)

Swales, John M. (1981) Aspects of Article Introductions. Birmingham, Language Studies Unit, University of Aston.

Swales, John M. (1990) Genre Analysis: English in Academic and Research Settings. Cambridge, Cambridge University Press.

Swales, John M. (2004) Research Genres. Explorations and Applications. Cambridge, Cambridge University Press. https://doi.org/10.1017/CBO9781139524827

Swales, John M. - Feak, Christine B. (2009) Abstracts and the Writing of Abstracts. Ann Arbor, University of Michigan Press.

Szathmári István (2004) Stilisztikai lexikon. Stilisztikai fogalmak magyarázata szépirodalmi példákkal szemléltetve. Budapest, Tinta Könyvkiadó.

Thomson, Pat - Kamler, Barbara (2013) Writing for peer reviewed journals. London, Routledge.

Tolcsvai Nagy Gábor (2001) A magyar nyelv szövegtana. Budapest, Nemzeti Tankönyvkiadó.

Veszelszki Ágnes (2015) Formális szövegek. In: Antalné Szabó Ágnes - Raátz Judit Veszelszki Ágnes (szerk.) Mozaikok a magyar nyelvröl és a nyelvhasználatról. Segédkönyv az anyanyelvi kritériumvizsgához. Bölcsészet- és Müvészetpedagógiai Tananyagok 10. Budapest, Eötvös Loránd Tudományegyetem. 108-120.

Veszelszki Ágnes (2016) Academic Writing, wissenschaftliches Schreiben, tudományos írás: Egyetemi hallgatók írásos produktumai - stilisztikai és grammatikai szempontból. In: Feld-Knapp Ilona (szerk.): Grammatik. Cathedra Magistrorum - Lehrerforschung, 3. Budapest, ELTE Eötvös József Collegium. 286-305.

\section{Az absztraktok forrásai}

http://semmelweis.hu/dei/files/2011/09/Farkas-Deb\%C3\%B3ra.pdf

http://onk2013.ektf.hu/wp-content/media/absztrakt-kotet-ONK-2013.pdf

http://www.dosz.hu/dokumentumfile/absztrakt_2015.pdf

https://fiatalokeuropaban.hu/wp-content/uploads/2016/10/FEU-Absztraktko\%CC\%88tet2016.pdf

http://www.tok.elte.hu/file/absztr_prog_japankonf_17.pdf

http://nyelvtud.btk.pte.hu/sites/nyelvtud.btk.pte.hu/files/files/manye2017/manye_absztraktkot et_0828.pdf

http://www.ecology.hu/abstractok/mtbk10-absztraktkotet.pdf

https://uni-eszterhazy.hu/public/uploads/okterv-konf-absztraktkot_56bb03ae08145.pdf

https://www.elte.hu/content/generaciok-nyelve.e.4719

http://www.filologia.hu/kivonatok/

http://www.botkozlem.elte.hu/hu/tart/2018t/BotKozlem\%20105\%201\%202018.pdf 
http://fizikaiszemle.hu

http://onk2017.hu/wp-content/uploads/2018/04/ONK_2018_aprilis.pdf

http://www.mkf.mke.org.hu/

http://etk.pte.hu/public/upload/files/tdk/konferenciak/20180504_05/TDK_AbsztraktKotet_20 18.pdf

http://www.uni-pen.hu/files/konferencia/2017/absztraktkotet2017.pdf

http://ri.btk.mta.hu/images/01_Tajregeszet_absztrakt_compressed.pdf

http://geohazardsconference.com/Absztrakt_kotet.pdf 